\title{
Curriculum Design, Linguistic Competence and Self-Actualization: A Case Study on English Curriculum Design for Chinese Non-English Major Postgraduates
}

\author{
Shangzhi Cai \\ School of Foreign Language, Yunnan Normal University, Kunming, China. \\ Email: e4294080@126.com \\ Received July $31^{\text {st }}, 2010$; revised September $9^{\text {th }}, 2010$; accepted September $30^{\text {th }}, 2010$.
}

\begin{abstract}
Studies conducted hitherto on English education for Chinese non-English major postgraduates have preponderantly focused on themes such as learning motivations, teaching or learning strategies, and various examinations. Yet little attention has been paid to the issue of curriculum design. In order to explore the correlations amongst curriculum design, linguistic competence and self-actualization, the author has carried out a survey on the English curriculum design for non-English major postgraduates in Yunnan Normal University by applying Maslow's theory of self-actualization. The survey reveals that postgraduates' reading abilities hold low correlation with self-actualization, thus priority should be given to improve their speaking proficiency as well as listening abilities. Besides, as a basic requirement for all postgraduates, academic writing receives the most attention since the quality of their graduate dissertation is considered as the ultimate indication of their self-actualization. Apart from providing concerning suggestions on the curriculum design according to the above findings, the author also holds that curriculum design is an autonomous, flexible and dynamic process. Hence, instead of sticking to the long-adopted uniform English curriculum for all non-English major postgraduates in China, more flexible curricula and requirements should be introduced in order to fulfill the self-actualization of postgraduates from different universities, different majors, and different regions.
\end{abstract}

Keywords: Curriculum Design, Linguistic Competence, Self-Actualization, Chinese Non-English Major Postgraduates

\section{Introduction}

It has been 17 years since the English Syllabus for Chinese Master's Degree Candidates (non-English major) was carried out in 1993. Unbelievably, there were few changes on it during these years. In China, almost every university still follows this syllabus to design English courses, thus similar courses and requirements can be found in different universities. On the other hand, there were many drastic changes in postgraduate enrollment, discipline categories and employment requirements. All of these situations call for new English Syllabus to guide specific curriculum design for non-English major postgraduates. The main aim of this paper is to explore the correlations among curriculum design, linguistic competence and self-actualization for Chinese non-English major postgraduates. And since most graduate schools in China base their English courses on the uniform syllabus, the author intends to adopt Yunnan Normal University as the study case to reveal certain general aspects in China. Accordingly, the core concerns in this study are as follows:

I. Which aspects of non-English major postgraduates' English linguistic competence can influence their needs of selfactualization? How these aspects are correlated to self-actualization?

II. What course and requirement should be designed for nonEnglish major postgraduates in order to serve their needs of self-actualization properly?

\section{Literature Review}

\section{Self-Actualization}

Self-actualization is a concept in Psychology. There are several expressions for this term such as self-fulfillment, self-realization, and self-actualization. Their general definitions will be provided as follows.

Cassel adopted a "Self-fulfillment Inventory" to assess selffulfillment. The assessment was founded upon the "cognitive dissonance" theory stated by Leon Festinger. In fact, the "cognitive dissonance" theory was initially derived from the concept of "free association" explained by Sigmund Freud, and for many years it has served as the basis of psychoanalysis (DeMoulin, 1999).

As Wehmeyer, Agran and Hughes stated:

Self-realization refers to the fact that people who are selfdetermined use a comprehensive and reasonably accurate knowledge of themselves and their strengths and limitations to act in such a manner as to capitalize on this knowledge (Eisenman $\&$ Tascione, 2002).

Ryff further identified six dimensions of self-realization from psychological angle, namely, self-acceptance, purpose in life, personal growth, positive relations with others, environmental mastery and autonomy. Each dimension implies certain challenges which individuals may encounter as they strive to function positively (Miquelon \& Vallerand, 2006).

According to Maslow, the term of self-actualization was first 
coined by Kurt Goldstein:

It refers to the desire for self-fulfillment, namely, to the tendency for him to become actualized in what he is potentially. This tendency might be phrased as the desire to become more and more what one is, to become everything that one is capable of becoming (Maslow, 1943).

Maslow further illustrated self-actualization concretely: "A musician must make music, an artist must paint, a poet must write, if he is to be ultimately at peace with himself. What a man can be, he must be (Maslow, 1943)." Maslow regarded self-actualization as one who can exploit and utilize his dower, talent and potentiality, realizing his own wishes, trying his best to do what is possible, and making himself perfect continuously (Maslow, 2003). He also deemed that self-actualization is different from each other because every person is a unique (Maslow, 1987).

Among the above mentioned concepts, self-actualization is used much wider than the others. Therefore, this paper will adopt this concept as the supportive theory.

\section{Curriculum Design}

Curriculum design has been an issue since 1940s. Tyler identified four fundamental questions which must be answered in developing any curriculum and plan of instruction:

1. What educational purposes should the school seek to attain?

2. What educational experiences can be provided that are likely to attain these purposes?

3. How can these educational experiences be effectively organized?

4. How can we determine whether these purposes are being attained? (Tyler, Luo, \& Zhang, 2008).

The above four goals are still effective in curriculum design until now. While selecting learning experiences as the curriculum resources, different scholars, however, hold different views on curriculum design. Brown and Richards et al. introduced the elements of curriculum and plan development (Brown, 2006; Richards, 2008). They offered the learners a number of teaching examples in order to help them to learn the process of curriculum design. Numan suggested that curriculum design should focus on the specification of the "what" of language teaching rather than the "how" (Numan, 2005). Isaacson et al., from the long run, recommended service-learning for the $21^{\text {st }}$ century curriculum design to cultivate communicative competence (Isaacson \& Saperstein, 2005). Luo probed into the English course design and the abilities of using language (Luo, 2001). She suggested that applied curriculum related to actual communication should be developed so that it can attain such a transition from basic study to real use. Based on learner-centered theory, Tang held that English teaching and curriculum design should meet the students' needs and social needs (Tang, 2003). Furthermore, Luxon et al., from another aspect, considered that curriculum development should serve foreign postgraduates' academic purposes in the context of internationalization (Luxon \& Peelo, 2009).

The calling for reform of postgraduate English curriculum design, virtually, began since the Syllabus of Master's Degree Candidates was carried out in 1993. Luo et al. and Tao analyzed the problems that existed in postgraduate English curriculum design and some other aspects that were not suitable for postgraduate education, and put forward some corresponding countermeasures (Luo \& Hao, 2001; Tao, 2001). English teaching for Master and Doctor should be oriented to EPP (English for Professional Purposes) (Qin, 2003). Founded upon the features of present English teaching for postgraduates, and the need of improving English speaking proficiency, Ke et al. brought forward a 'new pattern of curriculum. They suggested that a set of spoken textbooks should be compiled by the teachers according to the students' actual needs (Ke, He, \& Liu, 2005). Besides, in terms of postgraduate English course design, there are a number of scholars who have oppugned that the English course should be required or elective; or it should be taught respectively according to different English levels and competence in order to meet social needs and the students' individual needs (Zheng, 2006; Yuan, 2006; Dong, 2007; Li \& Li, 2007; Liu, 2008). In addition, Lu et al. considered that spoken English for non-English major postgraduates should be taught based on the constructivism theory (Lu \& Liu, 2009). Liu made the constructivism theory as the foundation and pointed out some existing problems in multimedia-teaching and offered the following countermeasures for how to get rid of such problems (Liu, 2009): (1) controlling information while adding comprehensible input; (2) more explanation and practice, paying much attention to the balance of the input and output; (3) more open practice in order to facilitate students' active thinking; (4) improving the quality of the courseware to stimulate students' study interest.

Post-modernism theory holds that curriculum is unfixed and shaped by various social needs. Curriculum program should follow W. Doll's theory to achieve the richness, recursion, relevance, rigor, and so forth (Zhong, 2008).

\section{Relationship between Self-Actualization and Curriculum Design or Teaching}

Since curriculum development leaders actively concern with a future in which school programs serve learners rather than handicapping them, they should be aware of studies that project onrushing forces and events (Wiles \& Bondi, 2004).

As early as 1940s, many scholars took notice of the relationship between self-actualization and curriculum design or teaching. Elizabeth deemed that exceptional children should be guided towards the attainment of self-realization through the integration of cores of interest in the curriculum (Elizabeth, 1948). Afterwards, Eisenman et al. investigated the responses of high school students with learning disabilities to a teacher's intervention intended to promote self-realization (Eisenman \& Tascione, 2002). Thomas explored the intersection of curriculum studies through the study of systems of reason that order reflection and action (Thomas, 2009). According to him, educators should 'grasp' some reality of learning, empowerment, problem-solving, self-realization, community, and to act upon. Irena insisted that significant school achievements which enable young people to achieve success in academic contests also have a decisive and positive importance for their self-actualization process (Irena, 1999). Bencze provided a curriculum framework in which priority was given to self-actualization (Bencze, 2000).

Han et al. held that it is the primary task for curriculum managers to design unique, practical and feasible curricula for college English (Han, Qi, \& Dai, 2009). Actually, it is similar 
to the postgraduates' English course design. Hence it is necessary for develop a local, practical and doable curriculum to serve the postgraduates' needs and social needs according to different universities in different regions. Such curriculum not only concerns with the competence of listening, speaking, reading and writing, but also concerns much about students' needs of self-actualization. It is worthy of mentioning that self-actualization is a broader personality-level variable than goals (Miquelon \& Vallerand, 2006). Therefore, the author just attempts to probe into some general goals for non-English major postgraduates to study English in China. In other words, this paper touches upon one aspect of self-actualization, that is, selfactualization in English learning.

\section{Subjects and Methodology}

\section{Subjects}

The subjects of this study are part of first-year postgraduates who major in Tourism, History, Mathematics, Chemistry and Biology. There were 100 subjects who participated in this investigation by means of questionnaire. 100 questionnaires have been distributed and 94 were taken back. Among the reclaimed questionnaires, 76 of them are valid. The validity is $80.9 \%$.

Meanwhile, there were 12 subjects who participated in the interview. 4 of them were from the Department of Tourism because this department has the most students amongst the selected departments. The rest 8 are from the majors of History, Mathematics, Chemistry and Biology respectively.

\section{Methodology}

Likert scale measurement was adopted to design this research questionnaire. Options are from totally disagree, disagree, no idea, agree and totally agree. The questionnaire consists of three parts with 47 multiple-choice questions and 3 open-ended questions (See Appendix I). The first part is the main one which consists of two sections (language competence and self-actualization), 42 multiple-choice questions (33 items for language competence and 9 items for self-actualization). It is worthy of mentioning that Linguistic Competence generally refers to one's abilities of speaking or performance in an acquired language. Self-actualization is an integrated need which can be adopted in evaluating the goals of English learning. The second part is about postgraduates' self-assessment. Three open-ended questions are consisted in the last part. The scores in the first part are scaled from 1 to 5. Questions for listening, speaking, reading and academic writing are negative. Consequently, if the total score is very high, it indicates that the participants are very weak in this aspect. On the contrary, the questions for selfactualization needs are positive. Hence the score should be accumulated in a reverse way. And the scores for the second part are from 5 tol. It refers to that the level of self-assessment of English proficiency is from excellent to flunk. All collected data was analyzed about its basic analysis and correlation analysis by SPSS 16.0 (Statistics Package for Social Sciences). In addition, because the question items are overcrowded, it is inevitable for participants to tick in the wrong place, which results in several missing values among the valid questionnaires. The missing values were handled through SPSS software. For the sake of intuitively seeing the correlations between English proficiency and self-actualization, Amos 5.0 software (Analysis of Moment Structure) was applied to process the structural equation model.

Besides, recorder was adopted in the process of interview. 15 short stories were prepared for the interviews. Each interviewee was required to read a story quietly before talking. After reading, every interviewee was asked to retell the main idea of the story by using his/her own words. Each interview lasted 15 to 20 minutes. Three themes, such as self-assessment on English language competence, self-actualization needs in English learning and expectations on English curriculum design, were mainly discussed during the interview. The whole process was conducted in Chinese. Then the qualitative data collected via interviews was thinly transcribed into English ultimately.

\section{Data Analysis}

\section{Interview Data Analysis}

In this part, the author plans to analyze the data collected through the interviews with 12 non-English major postgraduates in Yunnan Normal University. In corresponding to the research questions, three themes are touched upon: (1) selfassessment on English language competence; (2) the aspects which need to be improved to satisfy their self-actualization needs; (3) views on the rationality of English courses arrangement. The following summarizes these three themes accordingly.

(1) Self-assessment on English language competence

Eight of the interviewees could read the given story and gained the main idea consciously. However, it was difficult for them to orally paraphrase the main idea in English. During the interviews, they expressed that they were poor at English because they could not understand VOA, BBC, or even could not naturally conversing with a foreigner. Moreover, they also mentioned that their English writing was terrible. Once they wrote something in English, mistakes were always inevitable. Besides, two interviewees described their English as "just-so-so". Even if they could read the given materials easily or conjecture according to the context, they could not speak out in English. Also, other two declared that they were good at English. The proud reasons were: for example, they could get 71 and 74 in $\mathrm{GET}^{1}$ test and could communicate with a foreigner pretty fluently.

From the qualitative data analyzed above, it can be inferred that these interviewees assessed their English language competence mainly based on the three aspects: listening, speaking and writing rather than reading.

(2) Self-actualization needs in English learning

When asked the interviewees' about their goals of studying English, the answers were almost the same. To summarize their aims of studying English, there were five aspects concerned such as passing CET 6 and GET, writing thesis, going abroad if possible, and communicating with foreigners while going to the English Corner. The following is an excerpt from the interviewees' answers.

Question: "what kinds of goals do you want to achieve for studying English?"

Answers:

- "I want to pass CET 6 and GET. Only in this way can I 
graduate smoothly and find a comparatively good job."

- "I have taken CET 6 for five times, however, I failed five times because of the poor score in listening."

- "English education in our country is unsuccessful. I am one of the victims. I have studied English for more than ten years, but I cannot even speak fluently."

- "Through so many years' training, I can read the selected materials from textbooks. My only aim is to improve my listening, speaking and academic writing in order to go abroad for Ph. D study."

- "I can read and grasp the main idea of the English textbook in class. However, I cannot understand others and thus cannot speak with them in English Corner."

As the materials shown above, interviewees imparted that they mainly want to improve their listening, speaking and academic writing in order to achieve their goals.

(3) Views on English curriculum design

Nine interviewees deemed that English curriculum design was unreasonable. Reasons were various such as only one reading book, only one spoken lesson, no academic writing course, too many reading lessons (three or four per week), and so forth. Two interviewees thought that it would be better if there are one or more extra spoken lessons added; academic writing lessons were needed; and English textbooks were single (only one). One interviewee declared that reading lessons should be canceled. And various textbooks were required for different majors.

In brief, the interviewees are not content with the English curriculum designed for them. They are longing for different kinds of lessons and textbooks.

\section{Descriptive Statistics}

Quantitative data will be presented in the next three parts to further digitize the subjects' views on language competence, self-assessment and self-actualization.

From the basic descriptive statistics (Table 1), it seems that the mean for reading and self-assessment are lower than the others. It is because that the questions for listening, speaking, reading and academic writing are negative. Hence, if the sum score is very high, it indicates that the students are very weak in this aspect, and vice versa. The table shows that these subjects are good at reading more than other three aspects (such as speaking, listening and academic writing). And it can be inferred that they assess their linguistic competence mostly based on the proficiency of speaking, listening and academic writing. They deem that they are weak in the three parts, so they consider that they are weak in English all.

Through inferential statistics of pair comparisons of Repeated-Measures ANOVA (Table 2), it is obvious that mean differences among pairs are significant except this pair (speaking \& listening). From Table 1 , the data for speaking and listening is significantly higher than academic writing and reading. And From the data of inferential statistics (Table 2), we can see that mean difference between speaking and listening is not significant. Hence the students are much weaker at speaking and listening than academic writing and reading. Comparatively, they are weaker at academic writing than reading.

Table 1.

Mean and Std. Deviation.

\begin{tabular}{cccc}
\hline & N & Mean & Std. Deviation \\
\hline Speaking & 76 & 3.4624 & .85424 \\
Listening & 76 & 3.4539 & .86575 \\
Reading & 76 & 2.5846 & .84473 \\
Academic writing & 76 & 2.8433 & .68877 \\
Self-actualization & 76 & 2.8991 & .88316 \\
Self-assessment & 76 & 2.5263 & 1.11324 \\
\hline
\end{tabular}

Table 2.

Pair Wise Comparisons.

\begin{tabular}{ccccc}
\hline (I) factor1 & $(\mathbf{J})$ factor1 & Mean Difference (I-J) & Std. Error & Sig. $^{\text {a }}$ \\
\hline \multirow{2}{*}{ Speaking } & listening & .008 & .063 & .893 \\
& reading & $.878^{*}$ & .092 & .000 \\
& Academic writing & $.619^{*}$ & .067 & .000 \\
Listening & reading & $.869^{*}$ & .091 & .000 \\
Reading & Academic writing & $.611^{*}$ & .071 & .000 \\
\hline
\end{tabular}

Based on estimated marginal means 


\section{Correlation between Postgraduates' Linguistic Competence and Self-Assessment}

The statistics (Table 3) shows that Pearson Correlation coefficients for speaking, listening, reading and academic writing are $-0.686,-0.647,-0.500$ and $-0.667(\mathrm{r}=-0.686, \mathrm{r}=-0.647, \mathrm{r}$ $=-0.500, \mathrm{r}=-667 ; \mathrm{p}<.01)$. It indicates that the correlations among speaking, listening, reading, academic writing and self-assessment are moderately significant. Although the correlations amongst these four competence aspects and self-assessment are significant, there are still some differences existing. From Table 3, it is not difficult to see that the absolute values of Pearson Correlation coefficients of speaking, listening and academic writing are much higher than reading. It further confirms the data in Table 1. In other words, they are longing for improving their speaking, listening and academic writing. It is acceptable for a non-English major postgraduate who has studied English for almost ten years to hold such views.

The following will be another table for the correlations among self-actualization and speaking, listening, reading, and academic writing.

As it is shown in Table 4, the correlation between self-actualization and speaking, listening, academic writing achieves a significant level $(r=0.346, r=0.351, r=0.380, p<.01)$. The correlation between reading and self-actualization, however, is not significant at all $(r=0.186, p>.05)$. It seems that the subjects need proficient skills of speaking, listening and academic writing to actualize their potential expectations, instead of reading skills. Through face-to-face interviewing with 10 interviewees, they normally think that their reading proficiency is acceptable. They have little problems with reading. Even though sometimes there are a few words which are not familiar with, they can gain the main idea by conjecturing according to the context. Two of them express that they have the ability to guess a word's meaning after ten years drilling.

\section{Factor Analysis}

During the factor analysis process, in the section of language competence, 21 items about three factors (speaking \& listening, reading, and academic writing) are extracted. KMO value is 0.898 and the result of Bartlett's Test of Sphericity is signify- cant. Hence it is ideal for factor analysis. And the cumulative explained variance is $65.382 \%$. Besides, for the section of self-actualization, one factor ( 8 items) is extracted. KMO value is 0.888 and the result of Bartlett's Test of Sphericity is significant. Cumulative explained variance is $58.932 \%$. The index indicates that the result of the factor analysis is very good.

As it is shown in Figure 1 and Figure 2, the values of the factor loading are all above 0.6 . Hence the data is ideal for factor analysis. The following structural equation model will clearly reveal the correlations between self-actualization and English proficiency.

Through standardized regression analysis in AMOS 5, on one hand, the structural equation model (Figure 3) shows relatively lower correlation between reading competence and selfactualization (0.05). On the other hand, it shows relatively higher correlation among speaking \& listening, academic writing and self-actualization $(0.36$ and 0.18$)$. The model further confirms the findings in Table 4.

\section{Main Findings and Implications}

\section{Main Findings}

Through analyzing the above tables, we can find that reading abilities hold lower correlation with self-actualization (see Table 4), which is in line with the findings of Yan et al. ( $\mathrm{Li} \& \mathrm{Li}$, 2008). The survey also reveals that reading level is the best in all four aspects. Therefore most interviewees (see 4.1) show less interest to improve it comparing with other three. In this concern, priority should be given to improve speaking skills. It is with- out demur that speaking is a very important aspect which all postgraduates are keen to improve. It exactly corroborates a grotesque phenomenon, which is the fact that, in today's China, many postgraduates always complain that they have studied English year by year to cope with different kinds of examinations. While in actual use, however, they cannot even express a simple sentence correctly. Almost every respondent shows a strong aspiration for improving their English application abilities, especially speaking competence. It is the first step for a non-English major postgraduate to actualize himself in English learning.

Table 3.

Correlation between self-assessment and speaking, listening, reading, academic writing.

\begin{tabular}{rccccc}
\hline & & Speaking & Listening & Reading & Writing \\
\hline \multirow{3}{*}{ Self-assessment } & Pearson Correlation & $-.686^{* *}$ & $-.647^{* *}$ & $-.500^{* *}$ & $-.667^{* *}$ \\
& Sig. (2-tailed) & .000 & .000 & .000 & .000 \\
& $\mathbf{N}$ & 76 & 76 & 76 & 76 \\
\hline
\end{tabular}

${ }^{* *}$ Correlation is significant at the 0.01 level (2-tailed).

Table 4.

Correlation between self-actualization and speaking, listening, reading, academic writing.

\begin{tabular}{cccccc}
\hline & & Speaking & Listening & Reading & Writing \\
\hline \multirow{3}{*}{ Self-actualization } & Pearson Correlation & $.346^{* *}$ & $.351^{* *}$ & .186 & $.380^{* *}$ \\
& Sig. (2-tailed) & .002 & .002 & .107 & .001 \\
& $\mathbf{N}$ & 76 & 76 & 76 & 76 \\
\hline
\end{tabular}

${ }^{* *}$ Correlation is significant at the 0.01 level (2-tailed). 


\begin{tabular}{lcc}
\hline \multicolumn{1}{c}{ Items } & Components \\
\cline { 2 - 3 } & $\begin{array}{c}\text { Speaking \& } \\
\text { Listening }\end{array}$ & $\begin{array}{c}\text { Reading } \\
\text { Academic } \\
\text { Writing }\end{array}$ \\
\hline A1 Have difficulty giving a brief oral presentation & .643 & .628 \\
A7 Have difficulty retelling a text just read & .613 \\
B1 Have difficulty understanding lectures in English & .778 \\
B2 Have trouble taking effective notes while listening & .751 & .666 \\
B4 Have trouble understanding lengthy descriptions in English & .745 & .785 \\
B8 Have difficulty grasping the main idea while there are more than two people participating in & .683 & .775 \\
B3-1 ${ }^{2}$ Have difficulty understanding others in a daily conversation & & .753 \\
B5-1 Have difficulty understanding the main idea of a description & .796 \\
B6-1 Have trouble understanding a speech in noisy condition & .724 \\
C1 Have trouble understanding the main points of a text & .771 \\
C3 Have trouble grasping the clue even with scanning & .821 \\
C4 Guessing unknown words with difficulty in a text & .752 \\
C5 Have trouble understanding the text organization & \\
C6 Have trouble understanding the writer's purpose & \\
C7 Have difficulty understanding the writer's attitude to a text & \\
C2-1 Have difficulty skimming and understanding the main idea & \\
D4 Cannot remember the words while writing & & .774 \\
D5 Cannot organize paragraphs better & & .739 \\
D7 Cannot express what I want to say clearly & & .698 \\
D6-1 Have difficulty expressing ideas appropriately & & .670 \\
D11-1 Have difficulty completing written tasks within the time available & .601 \\
\hline
\end{tabular}

Figure 1.

Factor analysis.

\begin{tabular}{lc}
\hline \multicolumn{1}{c}{ Items } & $\begin{array}{c}\text { Component } \\
\text { Self-actualization }\end{array}$ \\
\hline E1 Study English for future work & .819 \\
E2 English is helpful for the study of professional courses. & .784 \\
E3 Study English for thesis writing & .770 \\
E4 Study English for communication & .834 \\
E6 Study English for shopping & .791 \\
E7 Study English for going abroad & .790 \\
E8 Study English for enrich myself & .837 \\
E5-1 Study English for reporting & .767 \\
\hline a. 1 component extracted. & \\
\hline
\end{tabular}

Figure 2.

Factor analysis for self-actualization.

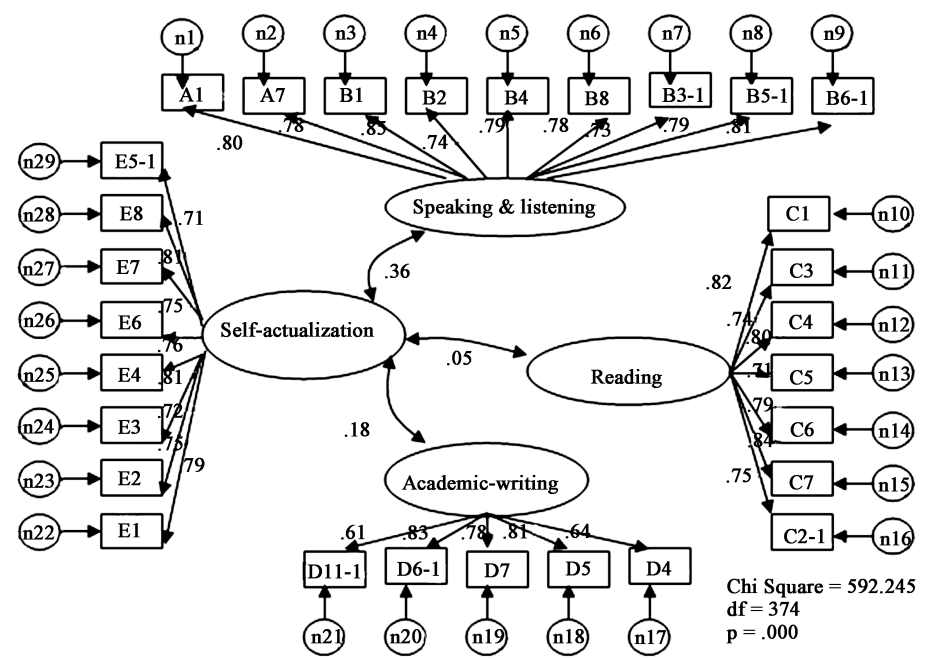

Figure 3.

A Structural equation model among the latent variables. 
It is of great importance to improve students' listening proficiency while talking about speaking, because every person is a social being, and communication exists everywhere. Therefore, the requirement for a speaker is not only the proficiency of speaking, but also the emphasis of listening. With the development of the international communication, Chinese postgraduates have more and more opportunities to present their academic studies in English. Although the advancement of the technology has brought us simultaneous translation, it is better for one to have good listening ability in case there is no simultaneous translation. And the simultaneous translation, after all, is no more than mechanical. Hence it is inevitable to make mistakes. In terms of the current situation, going abroad for further study or even living abroad is a flow for most postgraduates. Therefore, it is equally significant to improve listening ability while pursuing speaking proficiency. Effective communication in English can keep the speakers' sense of achievement alive so that their needs of self-actualization can be satisfied.

In addition, the author also found that postgraduates attach great importance on academic writing, which is in coincidence with the former scholars' findings (Qin, 2003; Luxon \& Peelo, 2009). As a postgraduate, academic writing is a basic requirement, because the quality of his/her graduate dissertation is considered as the ultimate indication of self-actualization. Consequently, it is urgent for the course designers or managers to pay more attention to the aspect of English academic writing.

\section{Implication}

\section{English Syllabus Design for Master's Degree Candidates}

An English Syllabus is a programmatic document guiding teaching and learning (Group, 2003). Most universities develop their courses by following the uniform Syllabus, including Yunnan Normal University which was investigated in this research. Different universities, however, have their regional characteristics. A uniform Syllabus cannot meet all needs of the universities and the postgraduate. This section will discuss what kind of English Syllabus should be designed for non-English major postgraduates.

As the statistics presented in part four, the subjects consider that their reading proficiency has achieved a reasonable level comparing with speaking, listening and academic writing. They can read academic and professional materials without big problems (see Interview Data Analysis, P.186). Their responses in the interviews further con- firm the statistic data shown above (see Table 4 and Figure 3). A majority of postgraduates argue that they are yearning for improving speaking, listening and academic writing rather than reading (see Interview Data Analysis, P.186). The English Syllabus of Master's Degree Candidates which has been carried out since 1993, however, attaches much importance to drill reading skills. For instance, the basic requirement of English teaching for non-English major postgraduates is to spare no effort to make their reading competence well. Mastering a number of words, possessing proficient reading skills, reading a lot and contacting with somewhat difficult articles are the key points of being excellent in reading. The main goal for postgraduates' English teaching is to cultivate the ability of reading professional works. Furthermore, English teaching should emphasize on reading, writing and translation (Sawyer, 2008).

The investigation, however, shows that postgraduates need the skills of speaking, listening and academic writing to achieve their self-actualization in the future (see Interview Data Analysis, P.186). Therefore, it is necessary to appeal to the leaders or scholars to ponder about redesigning a new English Syllabus, a growth model (Postgraduate English Instruction Association of Beijing, 2008). In order to keep pace with the development of the society and to meet the needs of the postgraduates' self-actualization. It is true that different regions have different ideas about the designing styles of Master's Degree English Syllabus. Qin has presented his suggestions for ESP (English for Special Needs) English Syllabus design in the following figure (Qin, 2003).

According to Figure 4, it is clear that different Master or Doctor Institutions can establish their own English requirements according to different professional characteristics and cultivating goals.

As far as the author is concerned, redesigning a new English Syllabus for non-English postgraduates is certainly necessary. In the new Syllabus, listening, speaking and academic writing competence should be added and stressed a lot. And cultivating reading skills can be weakened a little bit. In addition, according to actual situations of different universities, different required and elective English courses should be offered simultaneously for postgraduates. After all, the themes of growth and a
ESP Teaching Categories

Applied Ranges
Teaching Requirements
English for General Academic Purposes: EGP

English for Specific Academic Purposes: ESAP

English for Professional/Vocational/Occupational Purposes: EPP/EVP/EOP
For freshman \& sophomore (roughly equivalent to current CET-4 level)

For junior \& senior (roughly equivalent to post CET-4 level)

For advanced undergraduates \& non-English major Master and Doctor Candidates (EPP), incumbents (EVP/EOP)
A unified ESP teaching Requirement should be designed in order to unify a standard.

Different ESP teaching Requirements should be designed for different schools or majors.

Figure 4

Suggestions for ESP English Syllabus design.

No unified Requirement is required. Different graduate schools should have their own Requirements based on their cultivating aims and professional characteristics. 
developing rhetorical perspective are consistent throughout this history (Sawyer, 2008).

\section{Course Design}

The English textbook which is currently adopted in Yunnan Normal University is aiming at cultivating students' reading skills. For further reference, the main content of the textbook is given in Figure 5 (Ministry of Higher, 2007).

As the College English Curriculum Requirement presents, leaders of colleges or universities should take the school's circumstances into account while following the guidelines of the Requirement in designing College English course systems (Ministry of Higher, 2007), so does the Master's English curriculum design. Through the author's interviewing to 12 subjects and the questionnaire investigation, it reflects that many postgraduates are keen to improve their listening, speaking and academic writing skills, but not reading skills. Accordingly, English curriculum design should be based on the needs of the postgraduates' self-actualization. Adequate attention should be paid to train the abilities of listening, speaking and academic writing. Despite of the fact that there has been an English textbook for basic listening and speaking in this university, it is definitely insufficient to adopt only one version of English textbook. The materials about news report, job hunting, cross culture and so forth, are demanded in order to follow the flow of cultivating multiple applying talents. Moreover, no matter what materials will be adopted, students should be taken into account. And they should actually participate in each activity. As Confucius said, "I read and I forget; I see and I remember; I do and I understand (Isaacson \& Saperstein, 2005)." In fact, it is worthy of referring to the service-learning theory. Service-learning was first put forward by Isaacson et al. (Isaacson $\&$ Saperstein, 2005). This term describes a set of practices that involve students in various interactions with the community.

It is a pity that there are no such courses for training postgraduates' English academic writing in Yunnan Normal University. In fact, most postgraduates in China cannot receive relevant academic writing training although many of them aspire to drill their abilities in academic writing. As a scholar, no matter what the present or future is, academic writing is definitely necessary. As Qin has supported that English teaching for Master and Doctor Candidates should orient to professional

\begin{tabular}{ll}
\hline \multicolumn{1}{c}{ Unit } & \multicolumn{1}{c}{ Content } \\
\hline $\begin{array}{l}\text { One. Efficient } \\
\text { Reading }\end{array}$ & $\begin{array}{l}\text { Lesson 1. Developing Your Reading efficiency } \\
\text { Lesson 2. Developing Your Reading Flexibility } \\
\text { Lesson 3. Reading Rate }\end{array}$ \\
Two. Techniques for & Lesson 4. Skimming: Reading for Main Ideas \\
Efficient Reading & Lesson 5. Scanning: Rapidly Locating Information \\
& Lesson 6. Techniques for Reading Faster \\
Three. Active & Lesson 7. What Is Active Reading? \\
Reading & Lesson 8. Pre-reading \\
Four. Techniques for & Lesson 9. Connections \\
Remembering What & Lesson 10. Improving Your Concentration \\
You Read & Lesson 12. Remeasing Your Attention Span \\
Five. Developing & Lesson 13. Expanding Your Vocabulary (1) \\
Your Word Power & Lesson 14. Expanding Your Vocabulary (2) \\
& Lesson15. Aids to Vocabulary Development \\
\hline
\end{tabular}

Figure 5.

Outline of English textbook for non-English major postgraduates. purposes (Qin, 2003). Luxon et al. also deem that academic writing plays a key role in postgraduate education (Luxon \& Peelo, 2009). Hence more attention should be paid to academic writing during the course design.

Postmodernism curriculum theory stresses a lot on adaptability, variability and uncertainty of a course (Han, Qi, \& Dai, 2009), which implies curriculum is a dynamic concept. It should be different in different times and different regions. Accordingly, it is the primary task for the managers of universities to design unique, practical and feasible English courses for non-English major postgraduates.

\section{Arrangement of English Academic Writing Course}

As it is known to all, not every postgraduate's English proficiency can reach the average level. Hence English course for postgraduates cannot be uniform. For the sake of meeting the social needs and the students' self-actualization needs, English course for postgraduates should at least has two types: required and elective. The operational steps may be listed as following.

In the first place, it is suggested that all postgraduates should be examined for GET when they enter into the university at the very beginning. Then these postgraduates who have passed GET can be allowed to exempt from it, nay, they also can choose whether take Basic English course or not. There are some other English courses about spoken English, listening and academicEnglish writing, which are in relation to their own majors. These students can select several courses they like simultaneously. There should be another additional stipulation that is, no matter what kind of course they select, the English course on academic writing is always compulsory.

In the next step, for those who failed in the GET, they are required to study the Basic English at least during the first semester. Then at the end of the first semester, GET will be given to them again. And the qualified students will be allowed to enter into the above stage. Those who fail will continue to study the Basic English.

Last but not least, no matter a postgraduate has passed GET or not, he/she is required to take the an academic-English writing course after one-year study. The degree for those students who have selected this course from the beginning should be more difficult. Otherwise, they may feel that the course is repetitious and unattractive.

\section{Limitations}

There are some limitations in this survey. The number of subjects is 76 , so the sample size is comparatively small. Besides, in a few cases the respondents perhaps did not fully understand the questionnaires or missed some questions, which resulted in the existence of missing values in several valid questionnaires. Although the missing values were calculated by the statistic software, after all, they are just approximate values instead of the respondents' actual choices.

Moreover, there are not any separate items about reading in the section of self-actualization, which may arouse the question that how self-actualization and reading are correlated. Actually, self-actualization is an integrated notion about the goals of studying English. The author also regards reading ability as a basis for improving other aspects of English language competence. In fact, reading elements have been included in the self- 
actualization part of the questionnaire. For example, E1, E2 and E8 are integrated questions. Items like "future work", "the study of professional courses" and "enriching oneself" are more or less relevant to reading. Besides, the author also stresses this issue by analyzing qualitative data collected in face-to-face interviews.

Although the study is based on the case of Yunnan Normal University, as the author has stated in the introduction, almost every university in China still follows a uniform syllabus to design English courses so that similar courses and requirements can be found in different universities. Non-English major postgraduates in China, as far as the author knows, are facing many common problems in English learning. However, the author should admit that this study can only reflect some general, common situations in Chinese universities, but not every university in details. If data about two or more universities in different regions can be available, then more comprehensive understandings would be expected.

\section{Conclusion}

Based on the survey about the English curriculum design for non-English major postgraduates in Yunnan Normal University by applying Maslow's theory of self-actualization, this paper aims at exploring the correlations amongst curriculum design, linguistic competence and self-actualization. As the study shows above, postgraduates' reading abilities hold low correlation with self-actualization, thus priority should be given to improve their speaking proficiency as well as listening abilities. Effective communication in English can keep the sense of achievement alive so that their needs of self-actualization can be satisfied. Besides, as a basic requirement for all postgraduates, academic writing receives the most attention since the quality of their graduate dissertation is considered as the ultimate indication of their self-actualization.

Apart from providing concerning suggestions on the curriculum design according to the above findings, this study also reveals that course design is a dynamic process, which is in line with Xiao (Xiao, 2009). He has stated that competence is an open and dynamic system, so course design should also be open, dynamic, autonomous and flexible, as Choi supported that "the teachers can be agents of change, so do the students" (Choi, 2009). In a very real sense, curriculum is designed not for teachers, but ultimately for students. Therefore, students and teachers should equally participate in the curriculum design process. In addition, needs of self-actualization may be various as time goes by, curriculum design should be adapted accordingly. Hence, instead of sticking to the long-adopted uniform English Syllabus for all non-English major postgraduates in China, more flexible and practical syllabi and curricula should be introduced in order to fulfill the self-actualization of non-English major postgraduates at different universities, from different majors, and in different regions.

\section{Acknowledgements}

The author is greatly indebted to the subjects for their honest participation in this study. Special thanks to her supervisor Prof. Deying HU, whose instruction has contributed greatly to the completion of this paper. The author is also very grateful for
Prof. Mingsheng Li, Prof. Lisheng Li and Prof. Jieyun Duan for their helpful suggestions. Many thanks should be extended to Mr. Lin Li, M. Phil. candidate of the Chinese University of Hong Kong, for his insightful viewpoints. Thank Dr. Peng Li for his guidance on the statistical method. Sincere gratitude goes to the anonymous reviewer for his/her valuable revising suggestions on this paper.

\section{Notes}

1. "GET" is the abbreviation of Graduate Students English Qualifying Test

2. "B3-1" represents the item which is processed by Replaced Missing Values. There are several examples in this paper such as B5-1, B6-1, C2-1, D6-1, D11-1 and E5-1.

\section{References}

Bencze, J. L. (2000). Democratic constructivist science education: enabling egalitarian literacy and self-actualization. Journal of Curriculum Studies, 32, 847-865. doi:10.1080/00220270050167206

Brown, D. (2006). The elements of language curriculum: a systematic approach to program development. Boston, MA: Foreign Language Teaching and Research Press.

Choi, J. A. (2009). Reading educational philosophies in freedom writers. The Clear House, 82, 244-248. doi:10.3200/TCHS.82.5. 244-248

DeMoulin, D. F. (1999). Comparing the democratic maturity and self-fulfillment achievement of college juniors and seniors. College Student Journal, 33, 496-500.

Dong, J. W. (2007). Teachers professional development and the cultivation of english teachers: On designing the curriculum for the english education program at GDUFS. Journal of Guangdong University of Foreign Studies, 18, 96-99.

Eisenman, L. T., \& Tascione, L. (2002). How come nobody told me? Fostering Self-realization through a high school english curriculum Learning Disabilities Research \& Practice, 17, 35-46. doi:10.1111/1540-5826.00030

Elizabeth, M. K. (1948) Curriculum planning for exceptional children. Journal of Exceptional Children, 14, 130-133.

Group, W. (2003). Non-English major graduate english syllabus. Chongqing: Chongqing University Press.

Han, G. L., Qi, X. W., \& Dai, W. H. (2009). On the practice of multidimensional course design of college english. Foreign Language World, 2, 66-73.

Irena, P. S. (1999). Self-actualization and other personality dimensions as predictors of mental health of intellectually gifted students. Roeper Review, 22, 44-48. doi:10.1080/02783199909553997

Isaacson, R., \& Saperstein, J. (2005). The art and strategy of service-learning presentations. Florence, IT:Thomson Learning Academic Resource Center.

Ke, J. H., He, G. Y., \& Liu, Q. H. (2005). A new pattern of curriculum for postgraduate english. Higher Education Development and Evaluation, 21, 55-56.

Li, Y., \& Li, Y. (2008). Quality courses construction for non-english major postgraduate english. Research in Foreign Language \& Literature, 8, 59-65.

Liu, J. L. (2008). An investigation of postgraduate elective english course development. China Higher Education Research, 3, 42-45.

Liu, J. L. (2009). Going out of the misunderstandings of multi-media teaching and constructing a new pattern of postgraduate english teaching. China Higher Education Research, 2, 46-49.

Lu, X. Q., \& Liu, X. S. (2009). An exploration of non-english major postgraduate spoken english teaching. New Curriculum Research, 13, $71-72$.

Luo, C. L. (2001). Graduates' english curriculum design and lan- guage 
applying ability training. Research on Education Tsinghua University, 22, 151-155.

Luo, L. S., Yu J., \& Hao, M. (2001). Brief discussion on english course design in graduate level. Research on Education Tsinghua University, $10,156-159$.

Luxon, T., \& Peelo, M. (2009). Internationalization: Its implications for curriculum design and course development in uk higher education. Innovations in Education and Teaching International, 46, 51-60. doi:10.1080/14703290802646172

Maslow, A. H. (1943). A theory of human motivation. Psychological Review, 50, 370-396. doi:10.1037/h0054346

Maslow, A. H. (2003). Realizing the value of life. Hohhot, $\mathrm{CH}$ : Inner Mongolia People's Publishing House.

Maslow, A. H. (1987). Self-actualizing people. Beijing, Beijing: Sdxjoint Publishing Company.

Ministry of Higher (2007). College english curriculum requirement. Beijing: Higher Education Press.

Miquelon, P., \& Vallerand, R. J. (2006). Goal motives, well-being, and physical health: happiness and self-realization as psychological resources under challenge. Motiv Emot, 30, 259-272. doi:10.1007/ s11031-006-9043-8

Numan, D. (2005). The learner-centered curriculum. Shanghai, CH: Shanghai Foreign Educational Press.

Postgraduate English Instruction Association of Beijing (2008). A reading course for graduate student. Beijing: China Renmin University Press.

Qin, X. B. (2003). ESP nature, category and teaching principles. Journal of South China University of Technology (Social Science), 4, 79-83.
Richards, J. C. (2008). Curriculum development in language teaching. Cambridge, UK: Foreign Language Teaching and Research Press.

Sawyer, W. (2008). English teaching in new south wales since 1971: versions of growth? Changing English, 15, 2008, 323-337. doi:10.1080/13586840802364244

Tang, C. X. (2003). On postgraduate english instructional models of 'learner-centeredness'. Jiangsu Foreign Language Teaching and Research, 2, 20-24.

Tao, Y. L. (2001). The existing problems and countermeasures of postgraduate professional english teaching. Academic Degrees \& Graduate Education, 12, 25-27.

Tyler, W. R., Luo, K., \& Zhang, Y. (2008). Basic principles of curriculum and instruction. Chicago, USA: Chinese Light Industry Press.

Thomas, P. (2009). Curriculum study, curriculum history, and curriculum theory: the reason of reason. Journal of Curriculum Studies, 41, 301-319. doi:10.1080/00220270902777021

Wiles, J., \& Bondi, J. (2004). Curriculum development (p. 339). Foreign Language Teaching and Research Press.

Xiao, Y. (2009). Chinese and english understandings of 'competence' and their significance in curriculum design. Foreign Languages and Their Teaching, 8, 24-30.

Yuan, P. H. (2006). Humanistic psychology and humanistic language teaching. Shandong Foreign Language Teaching Journal, 111, 16-20.

Zheng, Y. Q. (2006). On the reform of english major curriculum design and creative talents cultivation model. Foreign Languages and Their Teaching, 8, 33-36.

Zhong, Q. Q. (2008). Curriculum logic. Shanghai: East China Normal University Press. 


\section{Appendix I. Questionnaire}

\section{A Survey on English Learning \& Course Design for Non-English Major Postgraduates}

Dear class,

Nice to meet you!

Thanks for your participation in this survey. The purpose of this survey is to examine how you learn English, what about your English course design and your real needs. Please carefully read and respond to each question. Of course, all data collected here will be only used for this study, and your questionnaire will be kept properly.

Thank you for your cooperation!

\section{Part 1: linguistic proficiency \& self-actualization needs}

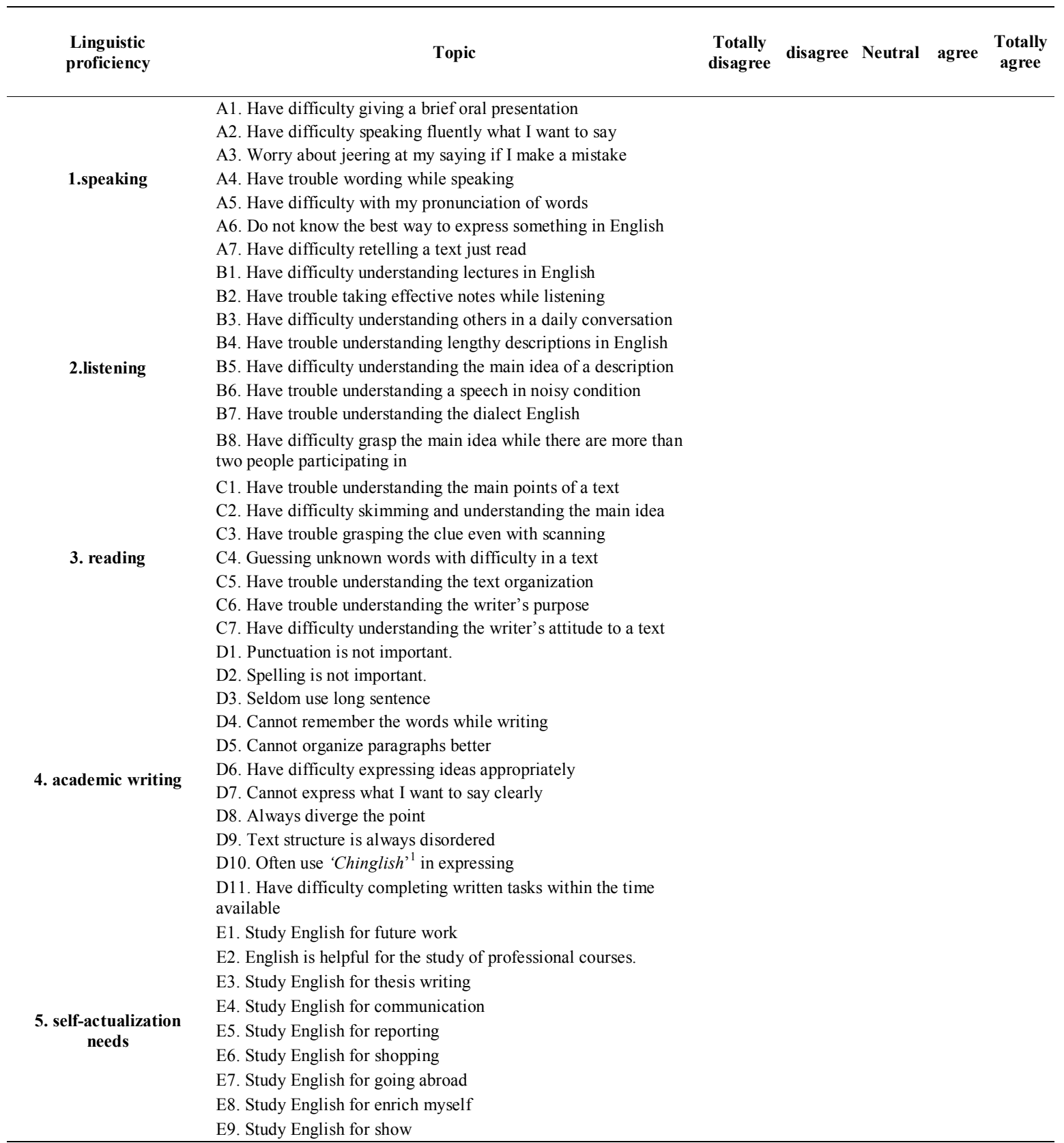

${ }^{1}$ Chinglish is a portmanteau of the words Chinese and English and refers to spoken or written English which is influenced by Chinese. See Jing, Xiao and Zuo, Niannian, (2006). "Chinglish in the oral work of non-English majors". CELEA Journal Vol. 29, No. 4. 


\section{Part 2: self - assessment}

Please evaluate your English level appropriately.

[ ] (Above 90 points) Advanced: able to converse on most topics fluently and naturally; use vocabulary, idioms, grammar, and pronunciation felicitously.

[ ] $\left(80-90\right.$ points) Intermediate ${ }^{+}$: can manage comfortably in familiar situations with familiar topics, though still some difficulty with vocabulary, idioms, grammar, and pronunciation.

[ ] (70 - 80 point) Intermediate- : reasonable fluency on a restricted range of topics but difficulty on an unlimited range of topics; many problems with words, idioms, grammar, and pronunciation.

[ ] (60 - 70 points) Basic ${ }^{+}$: know a limited number of common words and expressions; able to manage limited, short conversations on a few predictable topics; survival level knowledge of vocabulary, grammar, and idioms; pronunciation heavily influenced by mother tongue.

[ ] (under 60 points) basic: : know a few words and fixed expressions; cannot manage conversational exchanges; respond to question and answer exchanges on a few topics; very limited vocabulary, grammar, and knowledge idioms; pronunciation heavily influenced by mother tongue.

\section{Part 3: open-ended questions}

1. Do you think the current public English is useful for you? Why?

[ ] very useful [ ] useful [ ] useless

Reasons:

2. How many courses do you have in a week? How many of them are professional courses?

How do you think about the course design?

$[$ ] very reasonable $\quad[$ ] reasonable $\quad[$ ] not reasonable

Reasons:

3. Do you think it is necessary for postgraduates to take compulsory English courses? Why?

[ ] very necessary [ ] necessary [ ] not necessary

Reasons:

Appendix II English Syllabus Design (Qin 2003)

\begin{tabular}{lll}
\hline \multicolumn{1}{c}{ ESP Teaching Categories } & \multicolumn{1}{c}{ Applied Ranges } & Teaching Requirements \\
\hline $\begin{array}{l}\text { English for General Academic } \\
\text { Purposes: EGP }\end{array}$ & $\begin{array}{l}\text { English for Professional } \\
\text { /Vocational/Occupational Purposes: } \\
\text { EPP/EVP/EOP }\end{array}$ & $\begin{array}{l}\text { A unified ESP teaching Requirement should be designed } \\
\text { in order to unify a standard. }\end{array}$ \\
\hline
\end{tabular}

English for Specific Academic Purposes: ESAP
For junior \& senior (roughly equivalent to post CET-4 level)
Different ESP teaching Requirements should be designed for different schools or majors.
English for Professional /Vocational/Occupational Purposes: EPP/EVP/EOP
For advanced undergraduates \&non-English No unified Requirement is required. Different graduate major Master and Doctor Candidates (EPP), schools should have their own Requirements based on incumbents (EVP/EOP) 